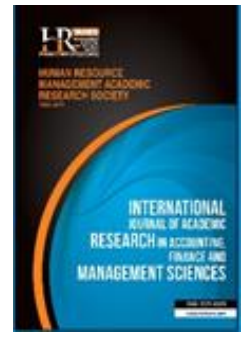

International Journal of Academic Research in Accounting, Finance and Management Sciences

Vol. 10, No.2, April 2020, pp. 140-156

E-ISSN: 2225-8329, P-ISSN: 2308-0337

(c) 2020 HRMARS

www.hrmars.com

To cite this article: Wijaya, A., Dio Caisar Darma, D. C., Pusriadi, T. (2020). How Contribute and the Growth of Regional Original Income? A Typology Empirical, International Journal of Academic Research in Accounting, Finance and Management Sciences 10 (2):140-156.

\title{
How Contribute and the Growth of Regional Original Income? A Typology Empirical
}

\author{
Adi Wijaya ${ }^{1}$, Dio Caisar Darma², Tommy Pusriadi ${ }^{3}$ \\ ${ }^{1}$ Program Studi Ilmu Ekonomi, Fakultas Ekonomi dan Bisnis, Universitas Mulawarman, \\ Samarinda, 75117, Indonesia, ${ }^{1}$ E-mail: adi.wijaya@feb.unmul.ac.id (Corresponding author) \\ 2,3Program Studi Manajemen, Sekolah Tinggi IImu Ekonomi Samarinda, Samarinda, \\ 75242, Indonesia, ${ }^{2}$ E-mail: diocaisar@stiesam.ac.id, ${ }^{3}$ E-mail: tommypusriadi@stiesam.ac.id
}

\begin{abstract}
The source of regional revenue is aimed at financing governance and development and to improve the welfare and prosperity of the community. The purpose of this study is to examine the contribution and the rate of growth of Regional Taxes, Regional Levies, Separated Regional Wealth Management Results, and Other Legitimate Regional Original Revenues to Regional Original Income in West Kutai Regency. Following the problems and objectives that have been formulated, the research approach is quantitative. In this study, secondary data based data sources during 2014-2018 were obtained from the Regional Revenue Service and the Central Statistics Agency of West Kutai Regency. To analyze the data, a contribution analysis, growth rate, and Klassen Typology analysis tool for each type of Regional Original Income is used against the overall total. Based on its contribution, Other Legitimate Regional Original Revenues are revenues with the highest contribution to the total of Regional Original Income. From the growth rate, the Regional Tax is the source of revenue of the Regional Original Income with the highest growth rate. Finally, the Klassen Typology analysis shows that Other Legitimate Regional Revenues can provide opportunities for an increase in the total Regional Original Income.
\end{abstract}

Key words

Contributions, Growth Rates, Klassen Typology, Local Own Revenue (PAD)

Received: 21 May $2020 \quad$ (c) The Authors 2020

Revised: 20 Jun 2020 Published by Human Resource Management Academic Research Society (www.hrmars.com)

Accepted: $\quad 30$ Jun $2020 \quad$ This article is published under the Creative Commons Attribution (CC BY 4.0) license. Anyone may reproduce, distribute, translate and create derivative works of this article (for both commercial and non-commercial purposes), subject to full attribution to the original publication and authors. The full terms of this license may be seen at: http://creativecommons.org/licences/by/4.0/legalcode

\section{Introduction}

Revenues (such as taxes) have an important role in development, especially for developing countries like Indonesia. The government needs to analyze matters relating to tax revenue because it is the basis for policymaking so that revenue realization is in accordance with the specified targets (Tarmidi et al., 2020; Agbo \& Nwadialor, 2020)

Local Own Revenue (PAD) has an important role in supporting the financial resources of a local government because it involves the independence of the region in financing government and development activities and providing services to the community that has contributed to the PAD (Saragih, 2013).

There has been a change in the policy on regional government regulation, namely the issuance at Law of the Republic of Indonesia No. 28 concerning Regional Taxes and Regional Levies, it is necessary to harmonize with the changes in the policy of local taxes and levies as a basis for local governments in exploring the potential of local revenue, especially PAD, this is because PAD is a financial source that is managed and managed local government by utilizing the potential that exists in the area so that it can 
provide opportunities for local governments to realize better governance and service to the community. Then, it is necessary to pay attention to the legal aspects of the regional tax component and regional user fees which have implications for their role in contributing to PAD. So that in the framework of local government to make efforts to increase PAD, it does not mean that the region must seek and make new regional taxes and levies, but rather try to utilize local tax revenues and levies optimally and reduce leakage of local tax revenues according to the authority given (Kuncoro, 2004; Darma, 2019).

Increasingly, funding for the implementation of government and development in the West Kutai Regency has always increased. Therefore, PAD is expected to be a reliable source of income in supporting the financial of West Kutai Regency and also as a financial source that can be used as a source of the development budget. Regional Tax Revenue, Regional Retribution, Management of Separated Regional Wealth and Other Legitimate PAD as a component of PAD is one source that shows a strategic position in the context of increasing the PAD of West Kutai Regency.

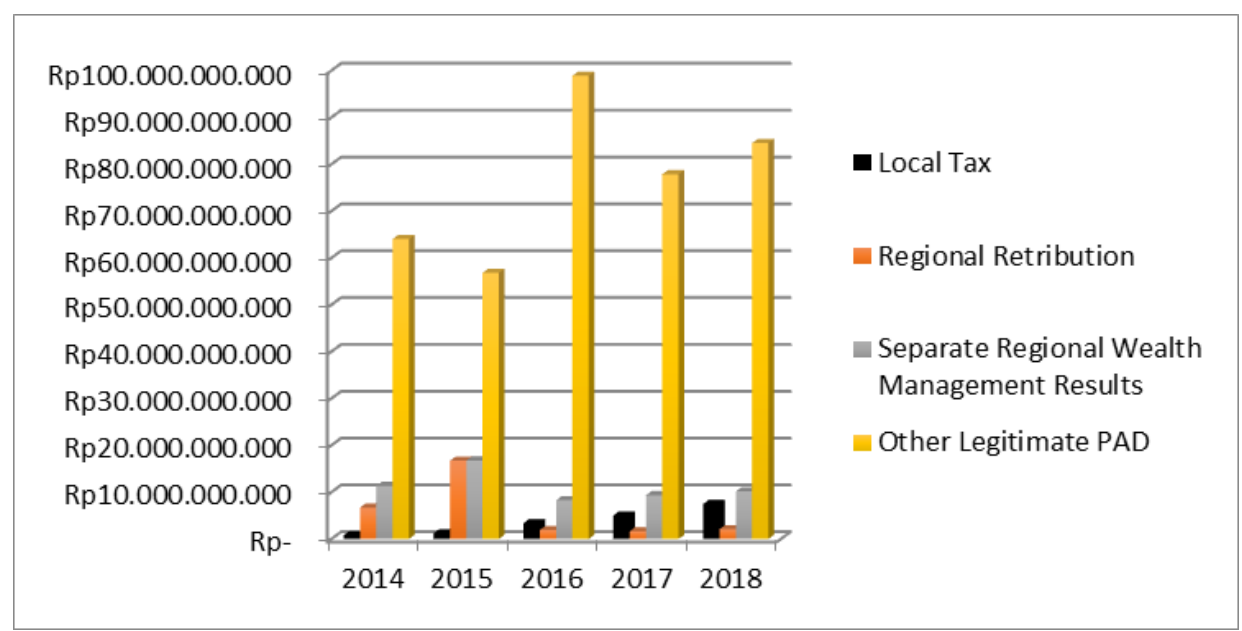

Figure 1. Normality test development of regional original realization realization by type revenue in West Kutai Regency, 2014-2018 (IDR)

Source: West Kutai Regency Regional Revenue Service (2019)

The development of PAD based on four sources or types of revenue in the past 5 years has consistently fluctuated. It can be explored if Other Legitimate PAD are the biggest source of revenue for PAD in West Kutai Regency. Miscellaneous Realization of the highest PAD that occurred in 2016 reached IDR 98,886,153,000 and the lowest in 2015 was IDR 56,809,031,000. Meanwhile, the results of the management of the separated regional assets were the second largest contributor to PAD revenue. The realization of the results of the Management of the Separated Regional Wealth occurred in 2015 reaching IDR $16,749,378,000$, and the lowest in 2016 of IDR 8,273,636,000. Furthermore, the third-largest source of revenue in the PAD of West Kutai Regency namely Regional Retribution with the highest realization occurred in 2015 reaching IDR 16,700,410,000, and the lowest in 2017 amounting to IDR 1,664,053,000. On the other hand, Local Tax is the source of revenue of West Kutai Regency PAD with the smallest contribution during the observation period. The biggest condition of the realization of the Regional Tax of West Kutai Regency occurred in 2018 which was IDR 7,460,233,000 and the lowest for 2014 was only IDR $804,722,000$.

The growth and contribution of the West Kutai Regency PAD are still small, so it can be said that the level of dependency of the West Kutai Regency Government on the central government is still very large. Although the dependency of the West Kutai Regency government on the central government is still very large, nevertheless as an autonomous region, the West Kutai Regency government must endeavor and try to explore its PAD by exploring existing potential sources.

Moreover, in the context of implementing regional autonomy, each region is demanded to be able to compete positively in economic activities if it does not want to be left behind by other regions, so the role of PAD becomes very important (because aside from being a source of government funding, regions are 
also used as benchmarks in the implementation of regional autonomy). The greater contribution of PAD to total regional income shows the financial independence of a local government, where the sources of PAD are expected to be a solution for regional funding and are expected to be the main buffer in financing government activities and regional development (Wijaya et al., 2019).

Related to this research, Halim \& Iqbal (2012) suggest that one of the big problems after regional autonomy is the dependence of regional governments on equalization funds from the central government. This is due to the still weak ability of local governments to manage the existing potential in the regions so that they can increase their PAD. Based on the description and see the existing conditions, then how important it is to know the contribution and growth of PAD in West Kutai Regency. Sources of regional revenue to finance governance, development, and aim to improve the welfare of the community, the researchers are interested in researching the contribution and growth of all types of PAD in West Kutai Regency, then classified in quadrants with the Klassen Typology analysis tool.

\section{Literature review}

Based on the Law of the Republic of Indonesia No. 17 of 2003 and government accounting standards, the structure of the Regional Revenue and Expenditure Budget is an integrated unit consisting of:

1. Regional Revenue is all cash receipts that are the right of the region and are recognized as an addition to the net worth in one fiscal year and do not need to be paid by the government again. The income group consists of:

a. Regional Original Revenue (PAD) is a regional income that is collected based on regional regulations under statutory regulations.

b. The Balancing Fund is a fund that is sourced from the revenue of the State Revenue and Expenditure Budget allocated to the regions in the context of the implementation of decentralization.

c. Other Legal Revenues are other income generated from assistance and balancing funds from the central government (Aslan et al., 2019).

2. Regional Expenditures are all regional cash disbursements or obligations that are recognized as a deduction from the net worth in a one-year budget period that will not be repaid by the government. Shopping groups consist of:

a. General Administration Expenditure (indirect expenditure) is the expenditure that is indirectly affected by the program or activity.

b. Operation and Maintenance (direct expenditure) expenditure is the expenditure that is directly affected by the program or activity.

c. Capital expenditure is a direct expenditure used to finance activities that will add assets.

d. Profit-Sharing Expenditures and Financial Assistance is a direct expenditure used in the provision of assistance in the form of money with no expectation of compensation.

e. Unexpected expenditure is an expenditure that is directly allocated to activities outside the plan, such as natural disasters.

f. Transfers are receipts/disbursements of money from another reporting entity, including balance funds and profit-sharing funds.

g. Financing is any revenue that needs to be paid back and/or expenditure to be received again, both in the relevant fiscal year and in subsequent fiscal years, which in government budgeting is primarily intended to cover deficits or take advantage of budget surpluses (Mardiasmo, 2004).

Based on the Law of the Republic of Indonesia No. 32 of 2004 which regulates the main points of government in the region does not mention the definition of revenue only components of PAD, which include: Regional Taxes, Regional Levies, Separated Regional Wealth Management Results, and Other Legitimate Revenues. To these considerations the political economy approach adds three additional reasons to avoid vertical fiscal gaps. First, as already mentioned, such gaps may subvert desirable fiscal competition among jurisdictions. Second, when states become more dependent on grants and less dependent on own-source revenue, their incentive to grow the local revenue base weakens (Careaga \& Weingast 2003; Weingast 2009; Darma et al., 2015).

Another understanding of PAD is the income or revenue of a region consisting of local taxes and levies, profits of regionally owned companies, the results of the management of regional wealth and other 
legitimate regional original income (Suparmoko, 2006). Performance is the achievement of what is planned, both by individuals and organizations. If the achievement is as planned, the performance will be carried out well. If the achievement exceeds what is planned, the performance can be said to be very good. If the achievement is not by what was planned or less than what was planned, then the performance is poor (Yasin, 2019).

Financial performance analysis is an effort to identify financial characteristics based on available financial statements. In government organizations to measure financial performance, there are several performance measures, namely the ratio of independence, effectiveness ratio, efficiency ratio, growth ratio, and harmony ratio. However, in this research, the contribution and growth ratio of the types of PAD is used. For this reason, the explanation relates only to the contribution and growth ratio of the type of PAD itself (Halim, 2001).

The relationship pattern of the financial capacity of a region (Province or Regency / City) is explained below (Table 1).

Table 1. Pattern of relationship of regional financial ability

\begin{tabular}{ccc}
\hline No. & Regional Financial Capability Ratio (\%) & Relationship Pattern \\
\hline 1. & $0.00-10.00$ & Verly less \\
2. & $10.01-20.01$ & Less \\
3. & $20.01-30.00$ & Enough \\
4. & $30.01-40.00$ & Medium \\
5. & $40.01-50.00$ & Well \\
6. & $>50.00$ & Very good \\
\hline
\end{tabular}

Source: Halim (2002); Asraf et al. (2019)

The determinants of growth and contribution to regional revenue are as follows: (1) Resource factors, which consist of both human resources such as labor, workability and physical resources such as work equipment, workplaces, and financial funds; (2) Organizational structure factors, namely the stable composition of positions, both structural and functional within an Agency/SKPD; (3) Technology factors for the implementation of work, support factors for the apparatus and their implementation, both leaders and the community; and (4) The leadership factor, in the sense of the ability to combine the four factors into a business that is efficient and effective in achieving the intended target (Budiarto, 2007).

Some reasons why the implementation of regional autonomy is very important because to provide opportunities for the region to get more money and freedom in financial management independently. In its implementation, the regional government is demanded to have greater financial independence. The ratio of regional financial independence can be done by increasing the realization of regional revenues, such as those from PAD (Ruliana, 2015; Sari et al., 2018).

PAD is a source of revenue from the Regional Government of West Kutai Regency which comes from the region itself based on its capabilities. Whereas Regional Tax, Regional Retribution, Separated Regional Wealth Management Results, and Others Legitimate Local Original Revenues have their contribution and growth rate which can affect the realization of PAD in West Kutai Regency.

The conceptual framework of this study regarding the typology of the contribution and growth of PAD is examined in Figure 2.

From this rationale, it can be seen that analyzing the contribution and growth rate of four types of PAD in West Kutai Regency is important, considering the potential of each component of different PAD caused by many factors. The ability to recognize the extent of the contribution and growth rate of PAD and utilize it optimally is an important thing that shows the capacity of West Kutai Regency in its management.

\section{Methodology of research}

To provide a clear picture of problem-solving and avoid misperceptions and understanding of the variables to be analyzed in this study, operational limitations on the components or variables of the research will be given as follows: 


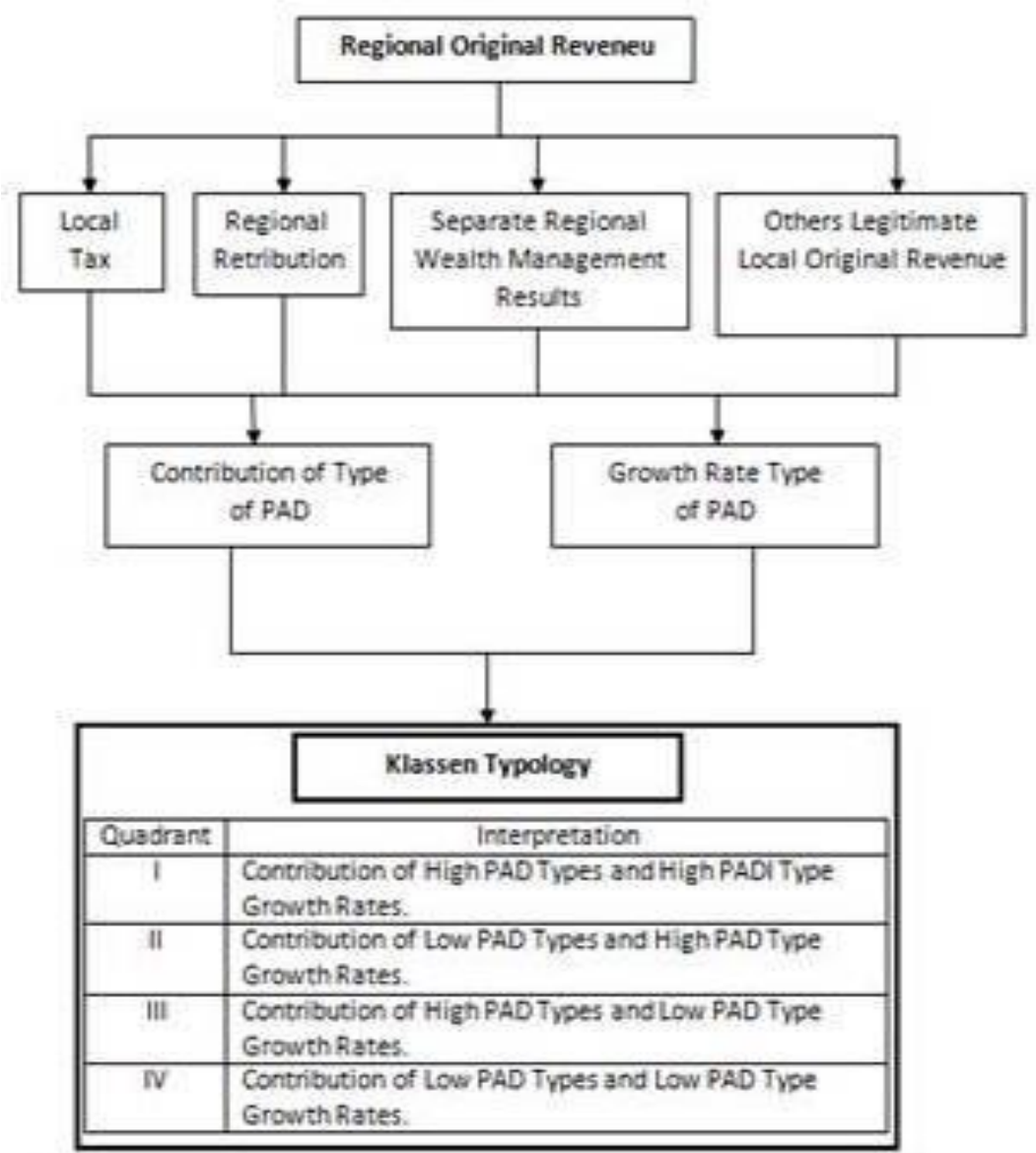

Figure 2. Study framework

1. Regional Original Revenue in West Kutai Regency is the realization of the amount of revenue sourced from Regional Taxes, Regional Levies, Results of Separated Regional Wealth Management, and (Others Legitimate Local Original Revenues, from 2014 to 2018.

2. Regional Tax is the realization of a total of nine types of taxes managed by the West Kutai Regency Regional Revenue Office to date, in the period 2014 to 2018.

3. Regional levies are the realization of the total revenues of 3 (three) types of levies managed by the West Kutai Regency Revenue Service to date, in the period 2014 to 2018.

4. Separation of Regional Wealth Management Results is the realization of the total revenue from two types of separated regional wealth management results managed by the Regional Revenue Service of West Kutai Regency to date, in the period 2014 to 2018.

Other Legitimate Regional Original Revenue is the realization of the amount of six other types of legitimate regional original income managed by the West Kutai Regency Revenue Office until now, in the period 2014-2018.

The data used are secondary data obtained from related agencies, offices, and offices within the West Kutai Regency Government. Secondary data needed in this study is the Original Revenue of West Kutai Regency which consists of four components, namely: Regional Tax, Regional Retribution, Separated Regional Wealth Management Results, and Other Legitimate PAD. The data was obtained from various sources of Government Agencies in West Kutai Regency, namely the Regional Revenue Service and the Central Statistics Agency.

The calculations used to measure local government financial growth are as follows (Halim, 2004; Sari et al., 2018):

Contribution of Type of PAD = (Realization of Type of PAD $) /($ Realization of PAD $) \times 100 \%$ 
Realization of PAD is revenue derived from levies (taxes/levies) or finances obtained from local companies and from services that are under the auspices of the local government as well as the routine and development budgets of the West Kutai Regency in the base year. Meanwhile, the realization of the type of PAD is the realization of the total or the amount of revenue sourced through Regional Taxes, Regional Levies, Results of Separated Regional Wealth Management, and Other Legitimate Local Original Revenues West Kutai Regency in the base year.

In this case, the capability of the regional government is measured by its revenue or regional income, one of which is through Regional Original Revenue. As for calculating the Growth of the Types of Regional Taxes, Regional Levies, Results of the Management of Separated Regional Assets and Other Legitimate Local Original Revenues in the PAD, the following formula is used (Halim, 2004; Sari et al., 2018):

$[\mathrm{Dx}=(\mathrm{Xt}-\mathrm{X}(\mathrm{t}-\mathrm{i})) /(\mathrm{X}(\mathrm{t}-\mathrm{i})) \times 100 \%]$

Where, $\mathrm{Dx}=$ Growth of Type of PAD per year, $\mathrm{Xt}=$ Realization of Type of PAD revenue in the base year, and $X(t-i)=$ Realization of Type of PAD Revenue in the previous year.

Through this analysis, we will get how much the contribution and growth of regional taxes, regional levies, the results of the management of the separated regional assets and other regional income to the original regional income that will be classified or categorized in the quadrant. If the potential for income is greater, it will provide opportunities for increased PAD and vice versa will provide for the reduction in PAD in West Kutai Regency.

Furthermore, after getting a value, as well as the average contribution and growth of each type of Local Original Revenue, the Klassen Typology method will map the types of PAD into a category in Quadrants I, II, III and IV based on the average indicator or calculation result of type of PAD to total PAD itself (Figure 3).

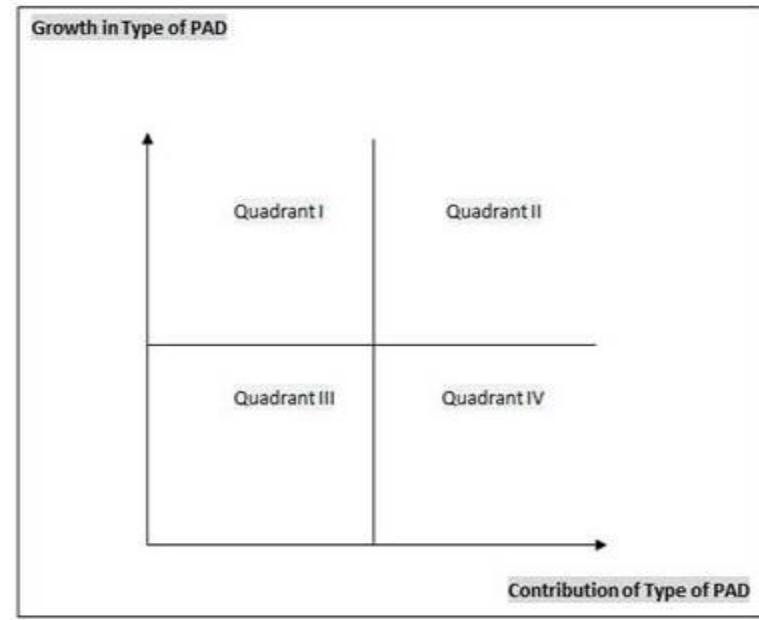

Figure 3. Klassen typology type of PAD

Source: Mahmudi (2009)

Then, the Klassen Typology criteria based on the types of PAD are classified according to quadrants from Table 2.

Table 2. Pattern of relationship of regional financial ability

\begin{tabular}{cl}
\hline Quadrant & \multicolumn{1}{c}{ Criteria } \\
\hline I & $\begin{array}{l}\text { Contribution of type of PAD (i) is high and growth of type of PAD (i) is high or fast growing (high } \\
\text { contribution and high growth). } \\
\text { Contribution of type of PAD (i) is low and growth of type of PAD (i) is high or potential (low } \\
\text { contribution and high growth). } \\
\text { III }\end{array} \quad \begin{array}{l}\text { Contribution of type of PAD (i) is high and growth of type of PAD (i) is low or developing (high } \\
\text { Contribution and low growth). } \\
\text { IV }\end{array} \quad \begin{array}{l}\text { Contribution of type of PAD (i) is low and growth of type of PAD (i) is low or depressed (low } \\
\text { contion and low growth). }\end{array}$ \\
\hline
\end{tabular}

Source: Mahmudi (2009) 
If the classification is examined, it becomes an analytical formulation or calculation can be seen in Table 3.

Table 3. Klassen's typology formula to the contribution and growth of PAD type

\begin{tabular}{cccc}
\hline \hline Growth in types of PAD & Contribution of type of PAD & yi $>y$ & yi<y \\
$(\mathrm{ri}>\mathrm{r}(+)$ & $(+)$ & I & $(-)$ \\
$\mathrm{ri}<\mathrm{r}(-)$ & $\mathrm{III}$ & $\mathrm{II}$ \\
\hline
\end{tabular}

Source: Sjafrizal (1997)

Where, yi = Contribution of types of PAD (i) to West Kutai Regency, $y=$ Average contribution to total types of PAD of West Kutai Regency, $r i=$ Growth of type of PAD (i) to West Kutai Regency, and $r=$ Average Growth of total types of PAD of West Kutai Regency. Then, the classification above through the predetermined size of this study is detailed as follows:

Table 4. Measuring classification of contribution and growth of PAD types according to Klassen typology

\begin{tabular}{ccl}
\hline No. & Measurement (\%) & \multicolumn{1}{c}{ Explanation } \\
\hline 1. & $\mathrm{yi}>\mathrm{y}$ & The contribution of types of PAD (i) is high \\
2. & $\mathrm{yi}<\mathrm{y}$ & The contribution of types of PAD (i) is low \\
3. & $\mathrm{ri}>\mathrm{r}$ & Growth in PAD (i) type is high \\
4. & $\mathrm{ri}<\mathrm{r}$ & PAD (i) type growth is low \\
\hline
\end{tabular}

Source: Mahmudi (2009)

To further simplify and speed up this analysis process, a computerized system using the Microsoft Excel program version 2010 is used.

\section{Results and discussions}

Based on research conducted and see the consistency of West Kutai Regency Revenue Structure data for 5 years, the research only limited the problem to analyze and study the sources of PAD, such as Regional Tax, Regional Retribution, Separated Regional Wealth Management Results, and Other Legitimate Local Original Revenues to PAD itself.

\subsection{Contribution Analysis Results}

First, the analysis of the contribution of Local Taxes in West Kutai Regency in the past 5 years shown by Figure 4 has experienced a significant increase, with a trend that is still positive. The results of the analysis note that the highest Local Tax contribution occurred in 2018 reaching $7.16 \%$ and the lowest in 2014 was $0.97 \%$.

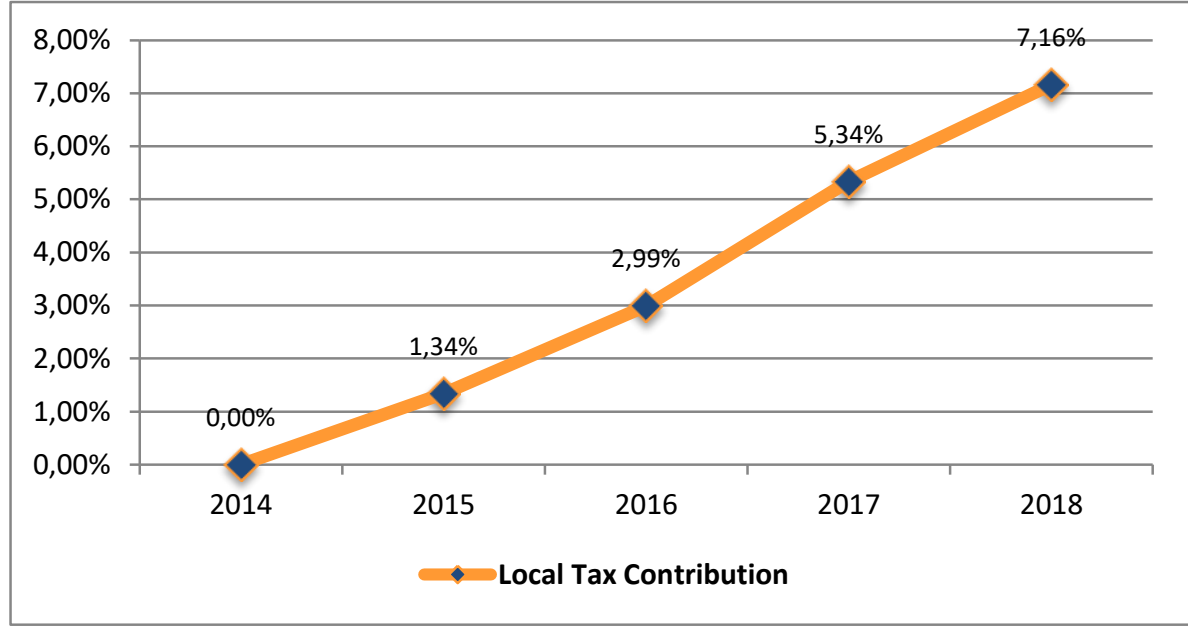

Figure 4. Local tax contribution in West Kutai Regency, 2014-2018 (\%)

Source: Analytical calculations 
Second, the analysis of the contribution of the Regional Retribution in the West Kutai Regency in 2014-2018 has shown to be volatile, with a downward trend. The results of the analysis revealed that the contribution of the highest Regional Retribution occurred in 2015 amounted to 18.25\% and the lowest in 2016 was $1.69 \%$ (Figure 5).

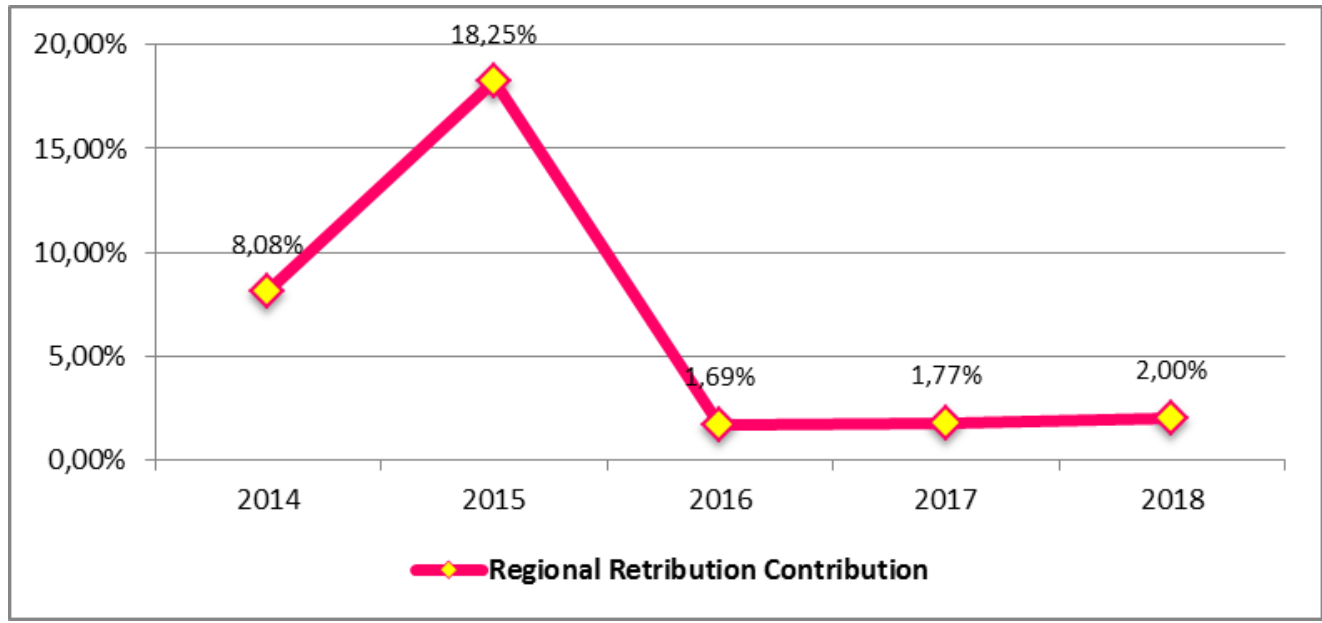

Figure 5. Contribution of regional retribution in West Kutai Regency, 2014-2018 (\%)

Source: Analytical calculations

Third, the analysis of the contribution of the results of the Management of Regional Assets Separated in West Kutai Regency for 5 years has fluctuated, with a downward trend. Figure 6 the highest contribution of the results of the Management of Separated Regions occurred in 2015 was $18.31 \%$ and the lowest in 2016 was $7.36 \%$.

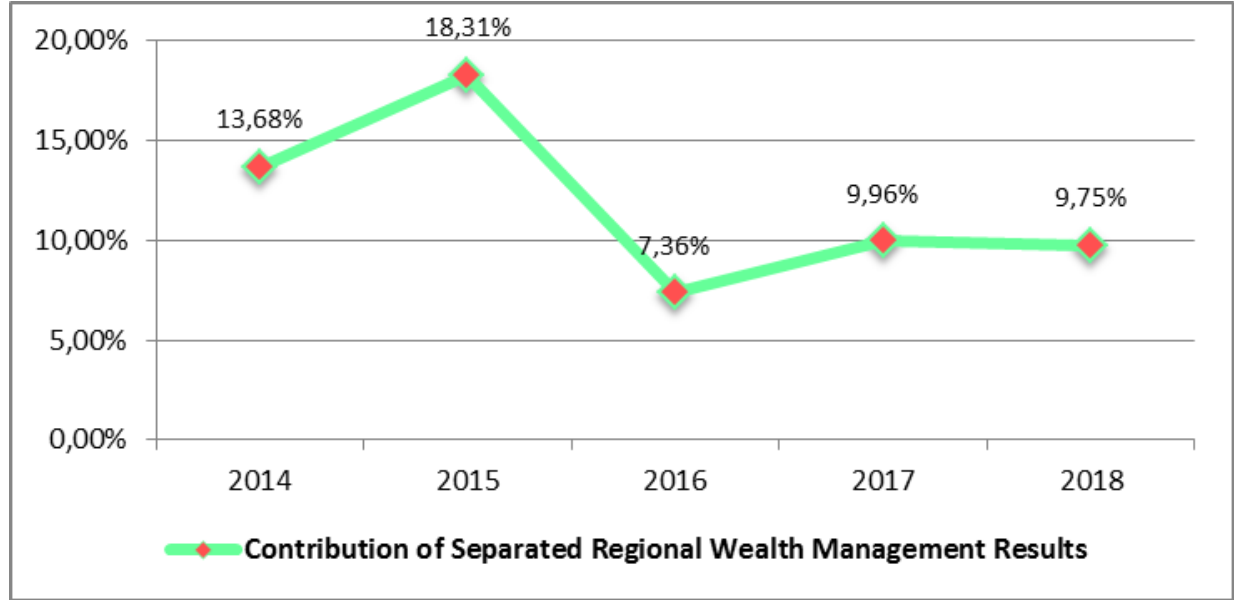

Figure 6. Contribution of separated regional wealth management results in West Kutai Regency,

$$
\text { 2014-2018 (\%) }
$$

Source: Analytical calculations

Fourth, Figure 7 in the analysis of the contribution of Other Legitimate PAD in West Kutai Regency also experienced fluctuations, although the trend was still positive in 2014-2018. The results of the analysis revealed that the contribution of Other Legitimate PAD was highest in 2016 reaching $87.96 \%$ and the lowest in 2015 at $62.10 \%$. When examined empirically according to real data and conditions occurring in the field, the achievement of Other PAD which is Legitimate West Kutai Regency gave the highest contribution to total PAD in the past 5 years, although there was a slight decrease in 2015. This is inseparable from several sources of revenue which in general from 2014 to 2018 increased, and had a 
significant role or share, such as realization: Income from Returns, Receipt of Interest on Deposits, and Receipt of Giro Services.

Results of Regional Wealth Management Separated with the second-highest contribution to total PAD in the period of observation, which is inseparable from the source of revenue which in outline continues to increase, and has a significant role or share, namely Equity Participation in Regional Development Banks (BPD) East Kalimantan Province.

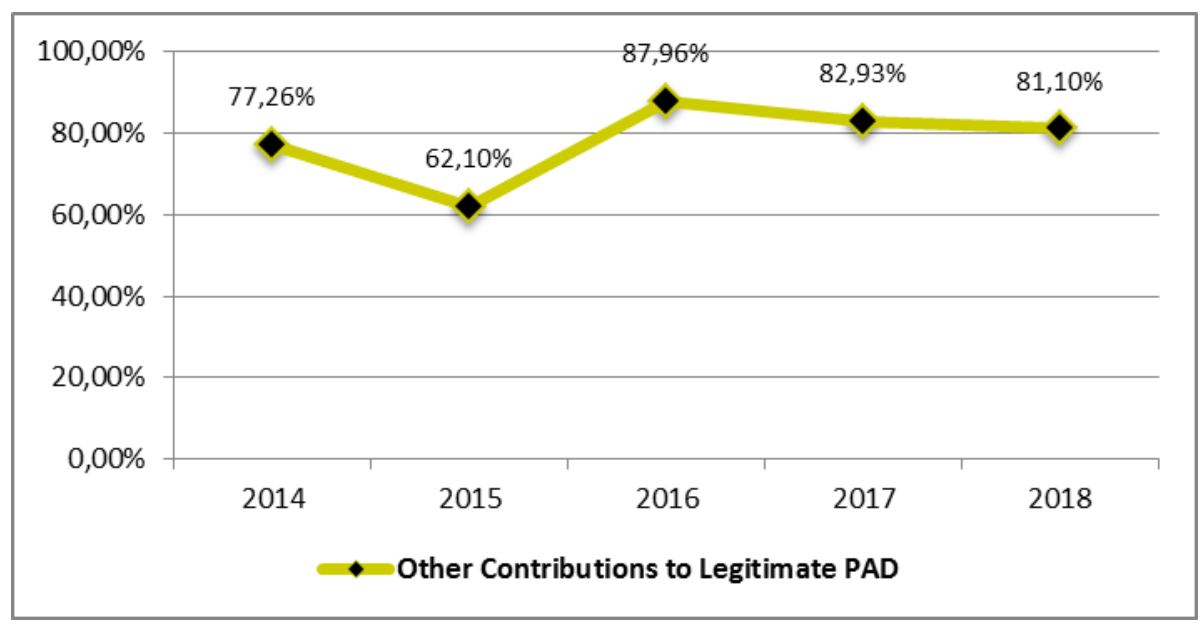

Figure 7. Other contributions of legitimate PAD in the West Kutai Regency, 2014-2018 (\%)

Source: Analytical calculations

Furthermore, the Regional Retribution of West Kutai Regency with the third-highest contribution to total PAD, which is inseparable from several sources of revenue which in outline in 5 years has also increased, and has a significant role or contribution, such as realization: Public Service Levies, Business Service Levies, and Certain Licensing Retribution. The West Kutai Regency Tax has the smallest contribution to the total PAD. Nevertheless, this is inseparable from several sources of revenue which in general have increased in 2014-2018, and have a significant role or contribution, namely realization: Road Lighting Taxes, Advertising Taxes, Hotel Taxes, Restaurant Taxes, and Nonmetallic Mineral Taxes and Rock.

\subsection{Results of Growth Analysis}

First, the analysis of the growth of Local Tax in West Kutai Regency in the past 5 years as shown in Figure 8 has fluctuated, with a trend that tends to be unstable. The analysis shows that the highest Local Tax growth occurred in 2016 reaching $173.90 \%$ and the lowest in 2014 to the point of $-7.98 \%$.

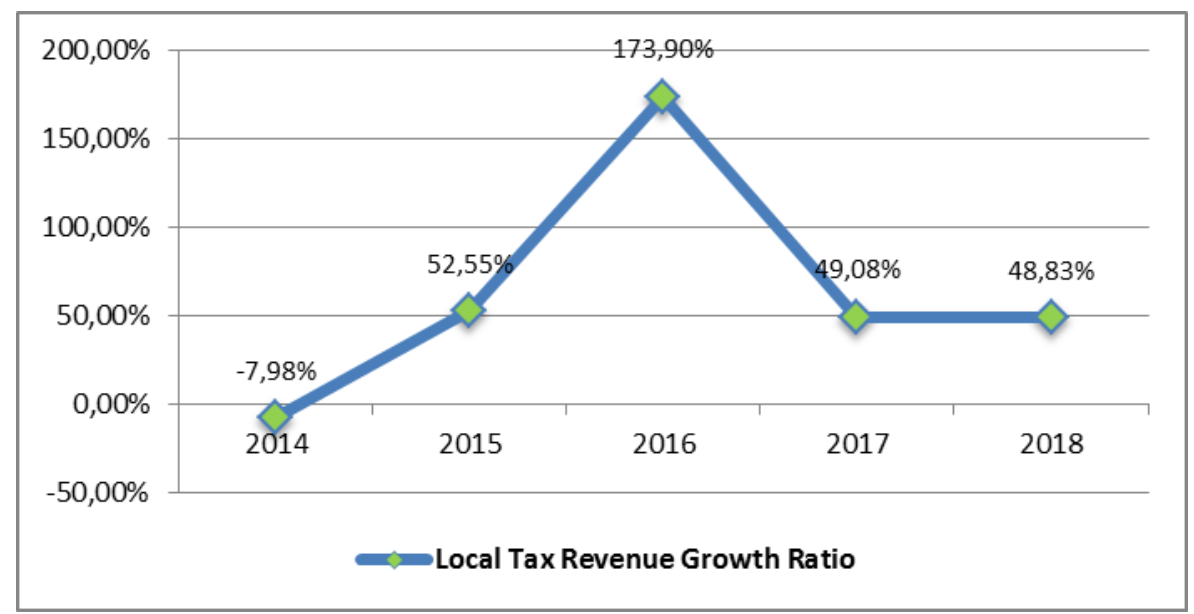

Figure 8. Local tax growth in West Kutai Regency, 2014-2018 (\%)

Source: Analytical calculations 
Second, growth analysis (growth) in the Regional Retribution of West Kutai Regency also experienced fluctuations, with an unstable trend. The results of the analysis revealed that the highest growth of regional levies occurred in 2015 reaching 149.29\% and the lowest in 2017 which amounted to $-88.60 \%$ (see Figure 9). Third, the analysis of growth (growth) for the Results of Regional Wealth Separated in the period of observation has fluctuated and unstable trends. During 2014-2018, the highest growth of Regional Assets Separated occurred in 2014 reaching 11,239.17\% and the lowest in 2016 which was $-50.60 \%$ (see Figure 10).

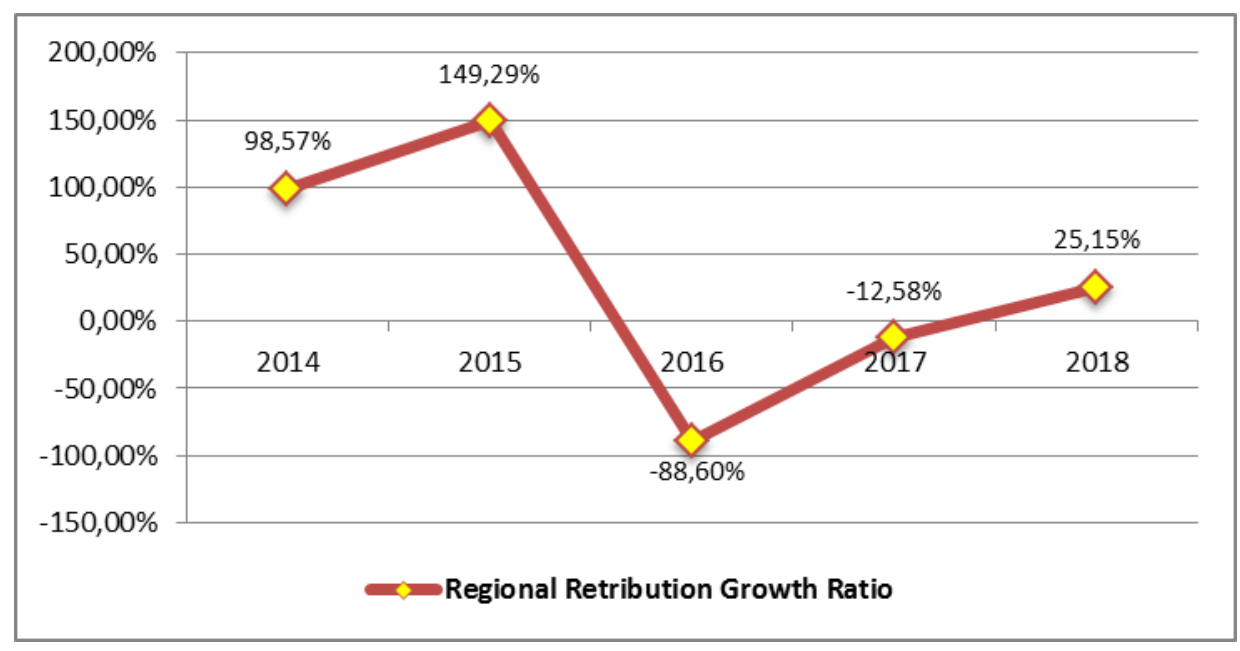

Figure 9. Growth of regional retribution in West Kutai Regency, 2014-2018 (\%)

Source: Analytical calculations

Fourth, the growth of Other sources of PAD that are legal for West Kutai Regency as shown in Figure 11 experienced fluctuations and unstable trends. Based on the analysis, it is known that the growth of Other PAD is the highest occurred in 2016 reaching $74.07 \%$ and the lowest in 2017 , amounting to $-21.27 \%$.

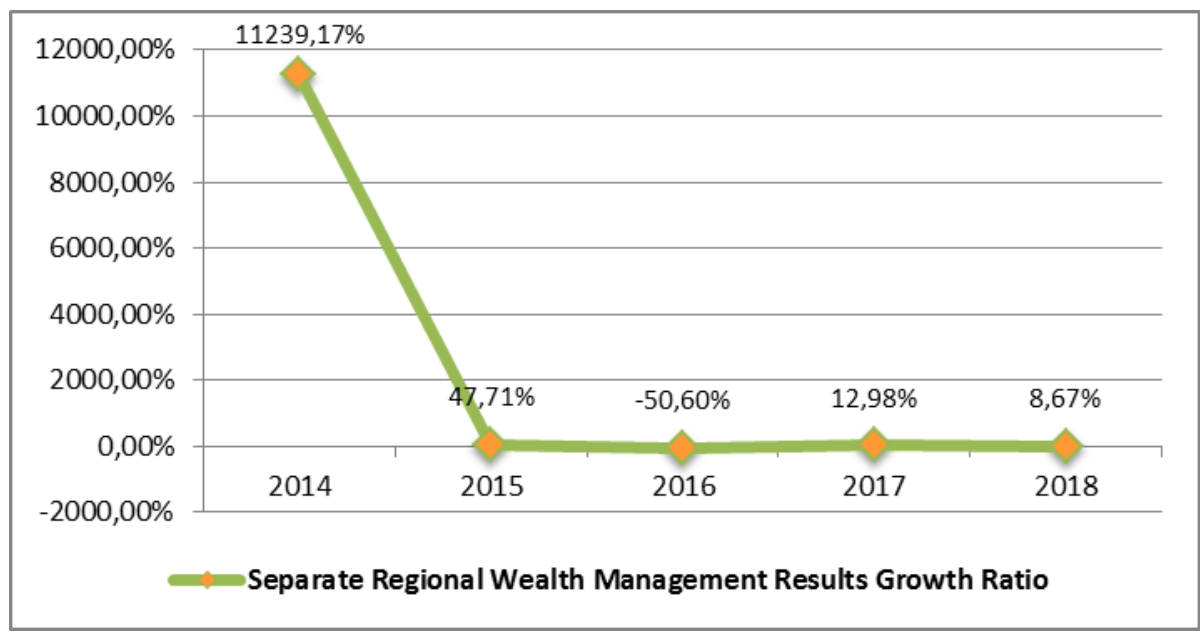

Figure 10. Growth in separated regional wealth results in West Kutai Regency, 2014-2018 (\%)

Source: Analytical calculations

When examined empirically according to the data and real conditions that occur in the field, the achievement of the West Kutai Regency Tax with the highest growth in the last 4 years, although the trend tends to decrease in 2017 and 2018. Then, the Retribution of the West Kutai Regency with the secondhighest growth when viewed during 5 years, high growth occurred in 2015. In 2016-2017 tended to decline with a negative trend and experienced an increase again for 2018. Furthermore, the results of the management of the separated regional assets have fluctuated from year to year with inconsistent trends from 2014 to 2018. Sources from Other Legal PAD also fluctuate during the period of observation. 


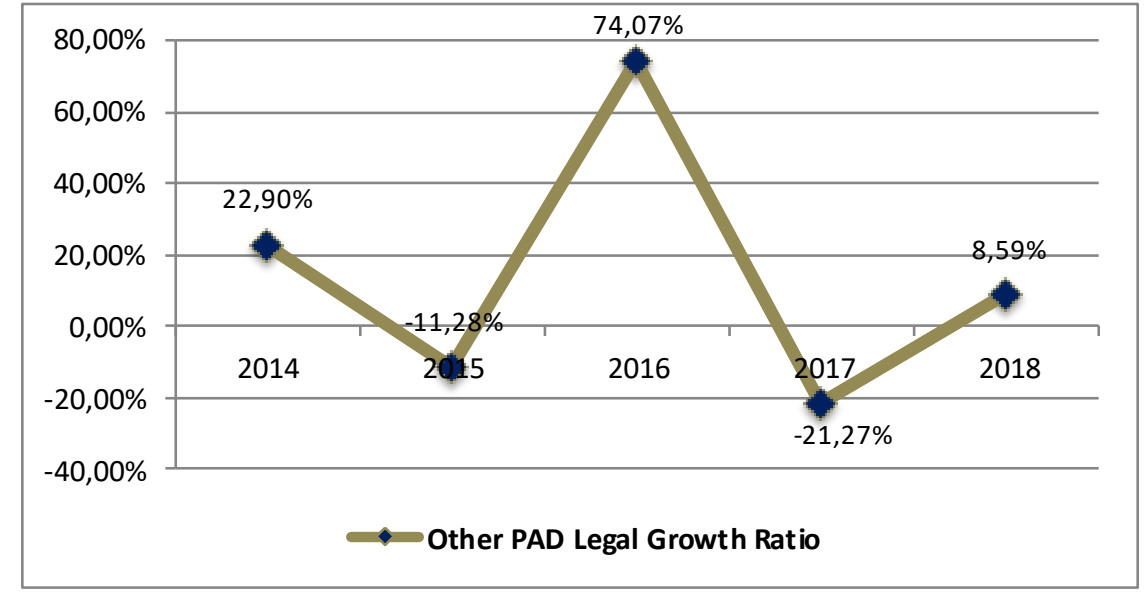

Figure 11. Other growth of legitimate PAD in West Kutai Regency, 2014-2018 (\%)

Source: Analytical calculations

PAD growth performance reflected in the type of revenue is an achievement of what is planned by West Kutai Regency. If the achievement will be per what was planned by the Government, the performance will be carried out well. If the achievement with the growth of types of PAD (Regional Tax and Regional Retribution) exceeds what was planned, it can be said that the performance of the West Kutai Regency Government is in a good category. Conversely, if the achievement is not under what has been designed or there are weaknesses, then the performance is in a bad category. Financial performance based on sources or types of regional revenue through PAD is a performance measure that uses growth indicators. Growth analysis carried out to assess the performance of PAD in West Kutai Regency in the past by carrying out various policies implemented so that a position or growth is obtained that represents the reality of the entity and potential financial performance that will continue in the future.

\subsection{Typological Analysis (Quadrant Classification)}

With the previous calculation formula, obtained the type of PAD West Kutai Regency from 2014 to 2018 with the quadrant classification and criteria, as follows:

Information for the 2014 results are: Quadrant II (contribution of the Regional Legality Management Results are low, but have high growth to PAD), Quadrant III (Other contributions of PAD are high, but have low growth towards PAD), Quadrant IV (the contribution of Local Taxes and Regional Retribution is low, and also the growth is low towards PAD), and none of the sources in PAD occupies the position of Quadrant I.

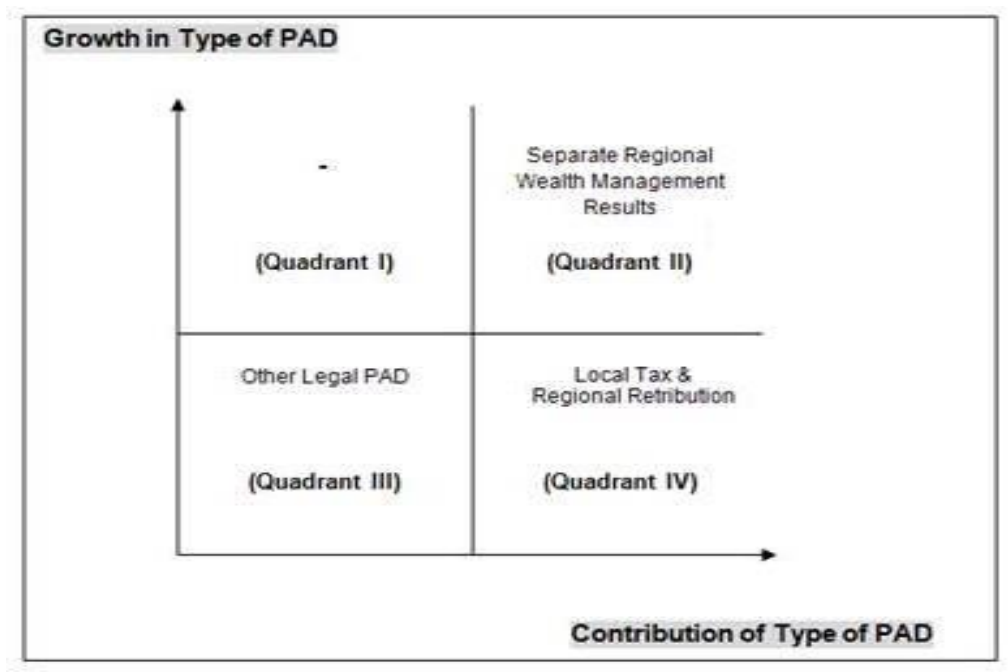

Figure 12. Results of typology analysis, 2014

Source: Analytical calculations 
As for the empirical study, it is known that the potential for revenue through contributions and growth, only the results of the Management of Separated Regional Wealth and Other PADs are legitimate if it provides an opportunity to increase the total PAD of West Kutai Regency in 2014. On the contrary, conditions are not ideal for Local Taxes and Regional Retribution provides an opportunity to decrease the total PAD of West Kutai Regency in 2014 (Figure 12).

Then, the criteria for the results of the Klassen Typology analysis based on the contribution and growth of types or sources of PAD in 2015 are classified in quadrants. In Figure 13, it is known that the potential for revenue through contributions and growth, only Regional Retribution and Other PADs are legitimate if it provides an opportunity to increase the total PAD of West Kutai Regency in 2015. However, on the contrary, conditions are not ideal for Regional Taxes and Results of Regional Wealth Management Separation provides an opportunity to reduce the total PAD of West Kutai Regency in 2015.

Similar to the previous year, there was no type of PAD in the Quadrant I criteria. Meanwhile, the contribution of Regional Retribution was low but had a high growth in PAD (Quadrant II), Other Contributions of PAD were high, but had a low growth in PAD (Quadrant III), and the contribution of Local Taxes and Legitimate Results of Regional Wealth Management is low, and also low growth towards PAD (Quadrant IV).

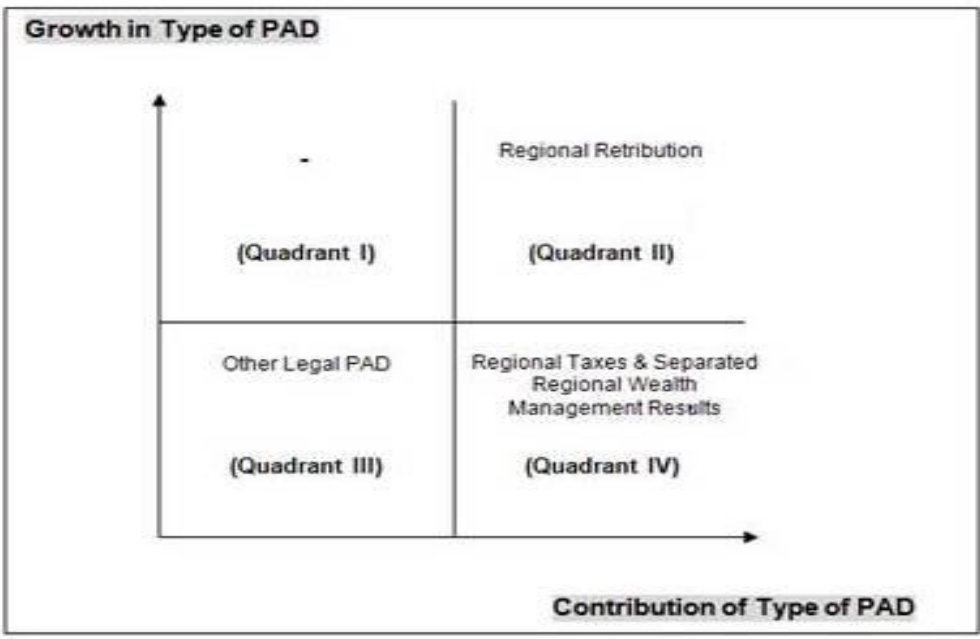

Figure 13. Results of typology analysis, 2015

Source: Analytical calculations

From 2016, criteria in typology based on the contribution and growth of types or sources of PAD, are classified in Figure 14.

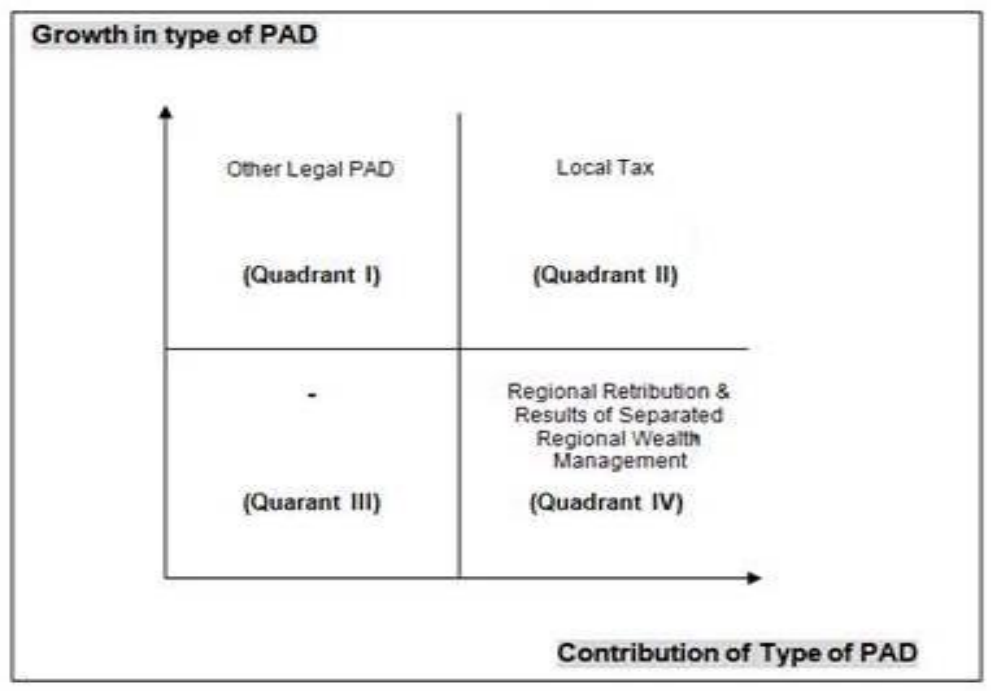

Figure 14. Results of typology analysis, 2016

Source: Analytical calculations 
This time, in the 2016 period there were no sources of PAD in the Quadrant III position. Quadrant I is Other contributions of high legitimate PAD, and also high growth of PAD, while Quadrant II is the contribution of low Local Taxes, but has high growth towards PAD, and contribution of Regional Retribution and Legitimate Results of Regional Wealth Management are low, and also low growth of PAD causes Quadrant IV. Potential through contribution and growth, only Other PAD that is Legitimate and Regional Taxes, if present opportunities for a total increase in West Kutai Regency's PAD in 2016. However, the opposite is not true for Regional Retribution and Regional Assets Management Results. PAD West Kutai Regency.

To see the typology performance based on the contribution and growth of types or sources of PAD in 2017, it appears that there are no types of PAD in Quadrant I. Whereas, Quadrant II (contributions of Regional Tax and Results of Separated Regional Wealth Management are low, but have high growth towards PAD), Quadrant III states that the contribution of Other PAD is legitimate high but has a low growth in PAD, and the contribution of Regional Retribution is low, and also low growth in PAD is included in Quadrant IV criteria. Carefully in Figure 15, the potential for revenue through contributions and growth, only Local Taxes, Results of Separated Regional Wealth Management and Other PADs are legitimate if they provide an opportunity to increase the total PAD of West Kutai Regency. But on the contrary, the condition is not ideal to occur in the Regional Retribution provides an opportunity to decrease the total PAD West Kutai Regency during 2017.

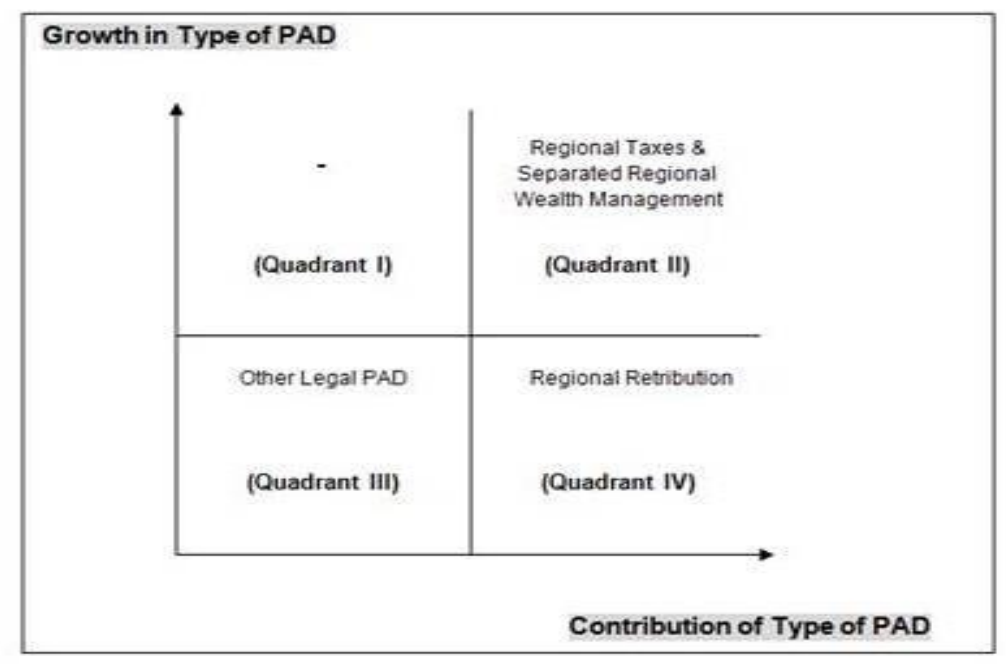

Figure 15. Results of typology analysis, 2017

Source: Analytical calculations

Similar to the observations of researchers in 2014, 2015 and 2017 if the potential for revenue is through contributions and growth, only Local Taxes, Regional Levies and Other PADs are legitimate if they provide an opportunity to increase the total PAD of West Kutai Regency in 2018. Figure 16, not ideal conditions occur the results of the management of the separated regional assets provide opportunities for a reduction in total PAD.

The criteria for each classification are Quadrant II (contribution of Regional Tax and Regional Retribution is low, but has a high growth in PAD), Quadrant III (Other contributions PAD is high, but has a low growth in PAD), and Quadrant IV (contribution to the Results of Management of Separated Regional Wealth is low, and growth is also low to PAD).

Carefully, it can be observed inconsistently during 2014-2017 there are differences in Quadrant position based on the findings of the existing analysis. However, what is often found is that almost none of the types of sources of revenue in the West Kutai Regency PAD are located in Quadrant I, except for 2016. Similarly, the results show that in 2018 there were no sources of revenue in Quadrant I (fast-growing). Meanwhile, Regional Tax and Regional Retribution occupy the position of Quadrant II (potential). In other directions, Other PADs are legitimately located in Quadrant III (developing) and the results of the Management of Separated Regional Wealth are found in Quadrant IV (depressed). 


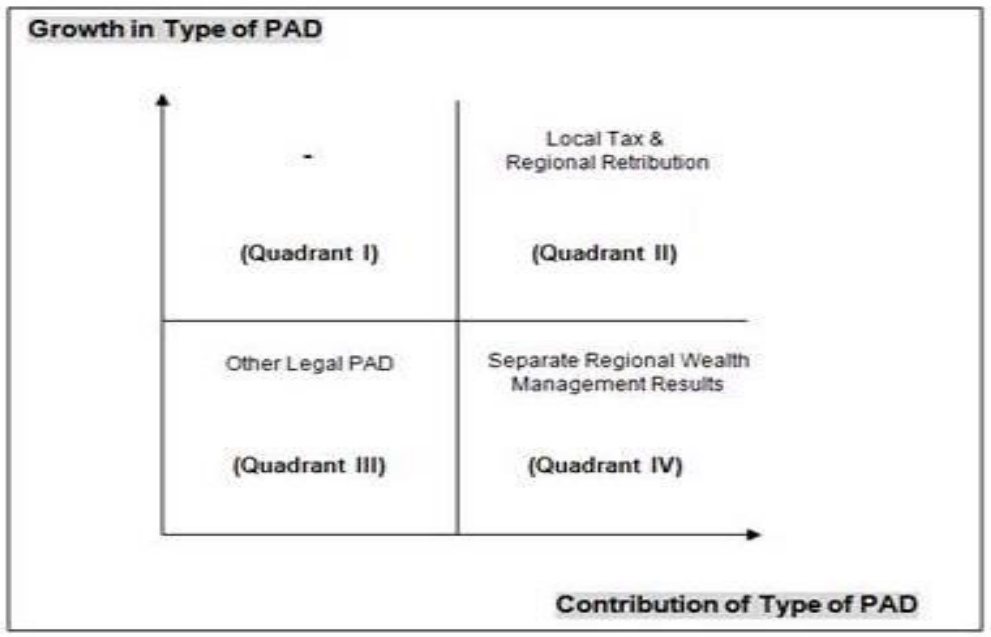

Figure 16. Results of typology analysis, 2018

Source: Analytical calculations

Field phenomena that occur in West Kutai Regency are to date only the Results of Management of Separated Regional Wealth and Other Legitimate PADs that can contribute to the revenue of the Government of West Kutai Regency, compared to Regional Taxes and Regional Retribution. The amount of contribution from Other Legitimate Regional Original Revenues is contributed from the types of revenue: Proceeds from the sale of Regional Assets that are not Separated, Demand Deposits, Interest on Deposits, Late Fees, Revenue from Returns, and Receipts from the Regional Public Hospital (RSUD) West Kutai. Then, the role of the contribution of the results of the Separation of Regional Wealth Management is contributed by the type of capital participation in the Regional Development Bank (BPD) of East Kalimantan in the past 5 years.

Meanwhile, the high growth of Regional Taxes and Regional Levies on the PAD of West Kutai Regency shows the ability of the West Kutai Regency Regional Revenue Service to manage the existing potential with quite high growth, although it fluctuates and contributes little to PAD. Examining the observations made by the author, to date there are still types of taxes and fees that have not been managed optimally with several factors, that is:

1. Hotel Tax, there are several problems, as the lack of awareness of hotel taxpayers whose tax determination is based on self-assessment in reporting hotel income data honestly and correctly every month, besides that in terms of the West Kutai Regency Government has not made hotel tax rate adjustments for hotel taxpayers the determination of the tax is based on the official assessment because it has not yet carried out the recording and bookkeeping.

2. Restaurant Tax, there are several problems, as the lack of awareness of restaurant taxpayers whose tax determination is based on self-assessment in reporting restaurant revenue data honestly and correctly every month, besides that in terms of the West Kutai Regency Government not yet making adjustments to restaurant tax rates for restaurant taxpayers the determination of the tax is based on the official assessment because it has not yet carried out the recording and bookkeeping. Then by the West Kutai Regency Revenue Service, it was found that a catering taxpayer did not report on catering service activities with mining companies.

3. Entertainment Tax, there is a problem that is still a lack of awareness of entertainment taxpayers whose tax determination is based on self-assessment in reporting income data from entertainment activities every month honestly and correctly.

4. Billboard Tax, there is a problem, as the rise of cigarette billboards and others by cigarette companies in public places such as food stalls, shops, and kiosks without reporting to the West Kutai Regency Revenue Service.

5. Public Street Lighting Tax (PPJU), as is a problem, namely the absence of electricity usage data obtained from sources other than PT. PLN so that the West Kutai Regency Dispenda cannot monitor PPJU 
which actually must be collected, other than that not-PLN PPJU users have not been registered in the Forestry and Plantation sector in West Kutai Regency.

6. Swallow Bird Nest Tax and Underground Water Tax which cannot be managed yet due to technical factors, as the absence of the West Kutai Regent's Regulation governing Swallow Bird Nest Tax Procedures and Procedures, whereas the Groundwater Tax turns out that until now the West Kutai Regency Dispenda has never done collection of data on individuals or bodies that use underground water.

7. In addition to the types of taxes above, there are still other types of taxes, as PBB P2 and BPHTB, which are only managed directly by the West Kutai Regency Government so that they have not been able to contribute optimally to the PAD of West Kutai Regency.

8. Public Service Levies, there are several problems which are not yet implemented Telecommunication Tower Control Levy due to the Constitutional Court Decree No. 46/PUU-XII/2014, then Parking Service Levies on the edge of Public Roads, Market Service Levies and Motorized Vehicle Testing Fees and Tera Levies that cannot be implemented because the structure and amount of tariffs are no longer appropriate.

9. Business Service Levies, there are several problems, namely not yet optimal management of the use of regional assets by other parties (Regional Property Usage Levies), terminal management (Terminal Levies), port management (Ports Levies Services). Also, there is no legal basis that regulates the levies on licenses to employ foreign workers and the levies on Ikutan Forest Products Exploitation.

The relevance of the empirical results to some previous studies has revealed that the effects of the distribution of corruption and tax evasion are regressive, thereby increasing income inequality. Regional income growth tends to assume that human capital is exogenous to income growth, so a more actual approach looks at the accounting ability to be simultaneous in the relationship between human resources and the output of that revenue growth. On the other hand, an approach through the assessment of accounting can help identify the most relevant variables and may have an impact on the path of future regional income growth (Hendriks et al.; 1998; Johnston, 1989; Cuaresma et al., 2017; Gyimah-Brempong \& Camacho, 2006; Leimbach et al., 2015).

In addition to the recording factor and the level of accountability, the role of innovation, creativity, the quality of the performance of the apparatus in the government sector, binding systems, and technology, are considered as equally important factors to support maximum regional income (Zainurossalamia et al., 2020).

\section{Conclusions, policy Implications and suggestions}

Others Legitimate PAD is the type of revenue with the highest contribution to the total PAD of West Kutai Regency during 2014-2018, despite fluctuations, but still with a positive trend. This is due to the role or shares of the sources in it, such as realization: Income from Returns, Receipt of Interest on Deposits, and Receipt of Giro Services in West Kutai Regency. Local Tax is the source of revenue with the highest growth ratio in PAD in West Kutai Regency in 2014-2018 despite fluctuations, but still with a positive trend until 2018. This is due to the role or share of the sources in it, such as realization: Hotel Taxes, Taxes Restaurants, Entertainment Taxes, Advertising Taxes, Street Lighting Taxes, Parking Taxes, Non-Metallic Mineral and Assistance Taxes, PBB, and West Kutai Regency BPHTB.

Referring to the Klassen Typology analysis, only Other PAD Legitimate are able to provide an opportunity to increase the total PAD of West Kutai Regency, because it is always in Quadrant III (developing) during the research period. Meanwhile, Regional Tax, Regional Retribution, and Regional Wealth Management Results tend to be unstable and dominant occupy quadrant IV (depressed).

In maximizing efforts to increase PAD in West Kutai Regency, it is necessary to conduct more intensive data collection on various sectors or types/sources of regional revenue that affect the increase in PAD of West Kutai Regency, particularly in the tourism sector through the collection of new restaurants and hotels. built, but not yet included as a taxpayer. Thus, it will improve the growth rate and contribution of Local Taxes, Regional Levies, Legitimate Results of Regional Wealth Management, and Other Legitimate PADs, which are expected to contribute to increasing the total PAD of West Kutai Regency. 
Always support the policies made by the West Kutai Regency Government which are constructive (participatory). Therefore, the resources owned by West Kutai Regency must be truly developed optimally, so that the goal of increasing PAD can be achieved.

So far, the Klassen Typology model is often used to compare the rate of economic growth with the Gross Regional Domestic Product (GRDP) per capita that is used as a reference or comparing the share of sectors, sub-sectors, businesses, commodities with an average value at a higher level or in national. Interestingly, the novelty of this study (albeit with the Klassen Typology analysis), however, is directed to categorize the merging of the quadrant with the acquisition of contributions and the growth rate of the types of revenue in PAD, namely: Regional Tax, Regional Retribution, Regional Wealth Management Results Separated, and Other Legitimate Local Original Revenues.

\section{References}

1. Agbo, E. I., \& Nwadialor, E. O. (2020). The Genesis and Development of Value Added Tax Administration: Case Study of Nigeria. International Journal of Academic Research in Accounting, Finance and Management Sciences, 10(2):15-30.

2. Anonymous. (2003). Law of the Republic of Indonesia Number 17 of 2003 concerning the structure of the Regional Revenue and Expenditure Budget. Jakarta.

3. Anonymous. (2004). Law of the Republic of Indonesia Number 32 of 2004 concerning Regional Government. Jakarta.

4. Anonymous. (2009). Law of the Republic of Indonesia Number 28 of 2009 concerning Regional Taxes and Regional Levies. Jakarta.

5. Anonymous. (2014). The decision of the Constitutional Court Number 46/PUU-XII/2014 in Testing the Law of the Republic of Indonesia Number 28 of 2009 concerning Regional Taxes and Regional Levies. Jakarta: Registrar and Secretariat General of the Constitutional Court of the Republic of Indonesia.

6. Aslan, A., Darma, D. C., Wijaya, A. (2019). Have Village Funds Impact Growth Economy and Poverty Rate?. International Journal of Scientific \& Technology Research, 8(10): 2601-2605.

7. Asraf, A., Lubis, M. S., Parpatih, Z. S., Sari, W. (2019). The Effect of Regional Original Income (PAD) and General Allocation Funds (DAU) on Capital Goods Expenditure in West Pasaman. e-Jurnal Apresiasi Ekonomi, 7(1): 30-37.

8. Budiarto, B. (2007). Pengukuran Keberhasilan Pengelolaan Keuangan Daerah. Seminar Ekonomi Daerah. Surabaya

9. Careaga, M., Weingast, B. R. (2003). Fiscal Federalism, Good Governance, and Economic Growth in Mexico. Princeton, NJ: Princeton University Press. In book: In Search of Prosperity: Analytic Narratives on Economic Growth. Princeton University Press.

10.Cuaresma, J. C., Doppelhofer, G., Huber, F., Piribauer, P. (2017). Human capital accumulation and long-term income growth projections for European regions. Journalof Regional Science, 2017(00): 1-19.

11.Darma, D. C., Haryadi, H., Umiyati, E. (2015). Potensi Sektor Perekonomian di Kabupaten West Kutai Provinsi Kalimantan Utara. Jurnal Perspektif Pembiayaan dan Pembangunan Daerah, 2(4): 173-180.

12.Darma, D. C. (2019). Determinants of the Gross Regional Domestic Product of East Kalimantan Province: Macroeconomic Variable Review. Review of Integrative Business and Economics Research, 9(1): 232-241.

13.Gyimah-Brempong, K., Camacho, S. M. (2006). Corruption, Growth, and Income Distribution: Are there Regional Differences?. Economics of Governance, 7: 245-269.

14.West Kutai Regency Regional Revenue Service. (2019). Realization of Regional Revenue of West Kutai Regency by Type of Revenue in 2014-2018. Annual Finance Report. West Kutai City: DISPENDA.

15. Halim, A. (2001). Bunga Rampai Manajemen Keuangan Daerah. Yogyakarta: UPP Akademi Manajemen Perusahaan YKPN.

16. Halim, A. (2002). Akuntansi sektor publik: Akuntansi keuangan daerah. Jakarta: Salemba Empat.

17. Halim, A. (2004). Akuntansi Keuangan Daerah. Jakarta: Salemba Empat.

18. Halim, A., Iqbal, M. (2012). Pengelolaan Keuangan Daerah: Seri Bunga Rampai Manajemen Keuangan Daerah, Edisi 3. Yogyakarta: Unit Penerbit dan Percetekan Sekolah Tinggi Ilmu Manajemen YKPN. 
19. Hendriks, J., Keen, M., Muthoo, A. (1998). Corruption, extortion and evasion. Discussion Paper No. 98/09. Cornwall: Department of Economics, University of Exeter.

20.Johnston, M. (1989). Corruption, inequality, and change. In: Peter M. Ward (ed) Corruption, development and inequality: soft touch or hard graft. London: Routledge.

21.Kuncoro, M. (2004). Otonomi Daerah dan Pembangunan Daerah: Reformasi, Perencanaan, Strategis dan Peluang. Jakarta: Erlangga.

22.Leimbach, M., Kriegler, E., Roming, M., Schwanitz, J. (2015). Future growth patterns of world regions - A GDP scenario approach. Global Environmental Change, 42: 215-225.

23.Mahmudi, M. (2009). Manajemen Keuangan Daerah. Jakarta: Erlangga.

24.Mardiasmo, M. (2004). Otonomi dan Manajemen Keuangan Daerah. Yogyakarta: Andi Offset.

25.Ruliana, T. (2015). Revenue Independence of East Kalimantan Province, Indonesian. Journal of Asian Scientific Research, 5(7): 340-348.

26.Saida Z., Darma, D. C., Kasuma, J., Ratnasari, S. L., Tasenţe, T. (2020). APparatus Performance as Mediation of Creativity and Innovation Towards the Successful Application of e-Kelurahan. European Journal of Human Resource Management Studies, 4(2): 108-126.

27.Saragih, P. J. (2003). Desentralisasi Fiskal dan Keuangan Daerah dalam Otonomi. Jakarta: Ghalia Indonesia.

28.Sari, P., Garvera, R. R., Sihabudin, A. A. (2018). What is the Contribution of Local Original Revenue to Regional Financial Independent?. Journal of Public Administration Studies, 3(2): 78-81.

29.Sjafrizal, S. (1997). Pertumbuhan Ekonomi dan Ketimpangan Regional Wilayah Indonesia Bagian Barat. PRISMA, 3(3): 27-38.

30.Suparmoko, M. (2006). Keungan Negara: Dalam Teori dan Praktik. Yogyakarta: BPFE Universitas Gadjah Mada.

31.Tarmidi, D., Sari, P. N., \& Handayani, R. (2020). Tax Avoidance: Impact of Financial and NonFinancial Factors. International Journal of Academic Research in Accounting, Finance and Management Sciences, 10(2): 1-8.

32.Weingast, B. R. (2009). Second generation fiscal federalism: The implications of fiscal incentives. Journal of Urban Economics, 65(3): 279-293.

33.Wijaya, A., Roy, J., Darma, D. C. (2019). Why Fiscal Dynamics Occur in Samarinda City?. Jurnal Ekonomi dan Studi Pembangunan, 11(2): 158-176.

34.Yasin, M. (2019). Analysis Of Regional Original Income Levels In Regional Financial Performance On Economic Growth In East Java Province. Archives of Business Research, 7(10): 222-229. 